\title{
Pathogen at the Gates: Human Cytomegalovirus Entry and Cell Tropism
}

\author{
Christopher C. Nguyen $\$ and Jeremy P. Kamil *®i \\ Department of Microbiology and Immunology, Louisiana State University Health Sciences Center, Shreveport, \\ LA 71103, USA; cnguy7@lsuhsc.edu \\ * Correspondence: jkamil@lsuhsc.edu
}

Received: 14 November 2018; Accepted: 5 December 2018; Published: 11 December 2018

\begin{abstract}
The past few years have brought substantial progress toward understanding how human cytomegalovirus (HCMV) enters the remarkably wide spectrum of cell types and tissues that it infects. Neuropilin-2 and platelet-derived growth factor receptor alpha (PDGFR $\alpha$ ) were identified as receptors, respectively, for the trimeric and pentameric glycoprotein $\mathrm{H} /$ glycoprotein $\mathrm{L}(\mathrm{gH} / \mathrm{gL})$ complexes that in large part govern HCMV cell tropism, while CD90 and CD147 were also found to play roles during entry. X-ray crystal structures for the proximal viral fusogen, glycoprotein $\mathrm{B}(\mathrm{gB})$, and for the pentameric $\mathrm{gH} / \mathrm{gL}$ complex (pentamer) have been solved. A novel virion $\mathrm{gH}$ complex consisting of gH bound to UL116 instead of gL was described, and findings supporting the existence of a stable complex between $\mathrm{gH} / \mathrm{gL}$ and $\mathrm{gB}$ were reported. Additional work indicates that the pentamer promotes a mode of cell-associated spread that resists antibody neutralization, as opposed to the trimeric $\mathrm{gH} / \mathrm{gL}$ complex (trimer), which appears to be broadly required for the infectivity of cell-free virions. Finally, viral factors such as UL148 and US16 were identified that can influence the incorporation of the alternative $\mathrm{gH} / \mathrm{gL}$ complexes into virions. We will review these advances and their implications for understanding HCMV entry and cell tropism.
\end{abstract}

Keywords: viral entry; glycoproteins; receptors; cytomegalovirus; herpesviruses; HCMV; CMV; pentamer; trimer; $\mathrm{gH} / \mathrm{gL}$

\section{Introduction}

HCMV exhibits a broad cell tropism that is reflected in the multifarious tissues and organs in which the virus causes disease [1]. Despite evidence that the virus alters its $\mathrm{gH} / \mathrm{gL}$ complexes in a manner that depends on the cell-type producing virus [2], the regulation of HCMV cell tropism is poorly understood. This review will focus on HCMV cell tropism as it relates to the viral entry machinery found in the virion envelope. Over the last several years, substantial progress has been made in this area. A number of new cellular receptors have been identified, and in two key examples, the newly identified cellular receptor is matched to a specific $\mathrm{gH} / \mathrm{gL}$ complex. Furthermore, a new $\mathrm{gH}$ complex has been characterized, and a number of viral factors that contribute to strain-specific differences in cell tropism have been described. Although there remain important unresolved questions, these advances provide a new level of clarity for understanding HCMV cell tropism and suggest new models to explain how HCMV enters cells and spreads within tissues.

\section{Viral Envelope Glycoprotein Complexes and Receptors}

Before the first complete HCMV genome sequence was published in 1990 [3], three major disulfide-linked viral envelope glycoprotein complexes had been described [4-6]. These complexes, originally designated as gC-I, gC-II, and gC-III, have turned out to play crucial roles in HCMV entry. 
The viral genes encoding the constituents of each complex are now known, as are the relationships to the conserved entry machinery shared among all herpesviruses. Therefore, the complexes are increasingly referred to by terms shared across the Herpesviridae, e.g., glycoprotein $\mathrm{H}$ /glycoprotein $\mathrm{L}$ (gH/gL), glycoprotein $\mathrm{B}(\mathrm{gB})$, glycoprotein $\mathrm{M}$ /glycoprotein $\mathrm{N}(\mathrm{gM} / \mathrm{gN})$. When a constituent gene product is unique to the betaherpesviruses or to HCMV, the name of that product is often used, e.g., gO (UL74) in the case of $\mathrm{gH} / \mathrm{gL} / \mathrm{gO}$ for trimer, or UL116 in the case of gH/UL116, the newly discovered gH complex with UL116 [7].

\section{3. $\mathrm{gB}$}

gC-I is made up of homotrimers of glycoprotein $\mathrm{B}(\mathrm{gB})$, a pan-Herpesviridae conserved glycoprotein posited to serve as the proximal mediator of membrane fusion events during viral entry. The threedimensional structures of post-fusion gB from herpes simplex virus-1 (HSV-1), HCMV, and the Epstein-Barr virus resemble those of glycoprotein $\mathrm{G}$ from the rhabdovirus vesicular stomatitis virus (VSV G) and of gp64 from the Autographa californica nuclear polyhedrosis virus, a baculovirus [8,9]. Together, VSV G, gp64, and gB comprise the class III membrane fusogens [10]. Based on inferences from the pre-fusion structure of VSV G, $\mathrm{gB}$ is thought to dramatically rearrange during membrane fusion. In its pre-fusion form, $\mathrm{gB}$ is thought to adopt a relatively flattened conformer in which the fusion loops are positioned at the base of the homotrimer, close to the viral membrane-hence, tucked away from the target membrane and set apart from one another. In the prevailing model, fusion occurs via a transitory intermediate in which the fusion loops reach out to the target membrane [10]. In the post-fusion configuration, three central helices line up at the core of the homotrimer, elongating the structure, and causing the fusion loops to cluster closer together at the side of the homotrimer opposite from where they began [11].

HCMV gB, which is encoded by UL55, is synthesized as a $160-\mathrm{kD}$ precursor that undergoes furin cleavage in the Golgi, resulting in $116 \mathrm{kD}$ and $55 \mathrm{kD}$ fragments that remain disulfide-linked to each other [12]. In 2015, two crystal structures of the post-fusion form of the HCMV gB ectodomain were published, both at up to $3.6 \AA$ resolution $[9,13]$. In one of the structures, the ectodomain was crystallized in complex with a recombinant Fab from a neutralizing antibody [9]. In a noteworthy development, a very recent cryo-electron tomography (cryoET) study reports the visualization at up to $21 \AA$ resolution of pre-fusion and post-fusion $\mathrm{gB}$ conformers on the envelope of native HCMV virions [14]. The pre-fusion gB homotrimer was described as a squat "Christmas tree-shaped" density (extending $130 \AA$ out from the membrane) compared to post-fusion homotrimers, which appeared taller and more columnar (extending $161 \AA$ from the membrane).

A number of cell-surface proteins have been reported or implicated as $\mathrm{gB}$ receptors, including the epidermal growth factor receptor (EGFR) [15], the platelet-derived growth factor receptor alpha (PDGFR $\alpha$ ) [16], and, as discussed further below, integrins [17,18]. On the other hand, it has also been suggested that $\mathrm{gB}$ functions as a viral fusogen that does not bind cellular receptors [19]. In light of the latter, attempts would seem warranted to visualize interactions between $\mathrm{gB}$ and its putative receptors by approaches such as cryo-electron microscopy (cryo-EM).

\section{4. $\mathrm{gM} / \mathrm{gN}$}

gC-II is comprised of a disulfide-linked heterodimer of glycoproteins $\mathrm{M}(\mathrm{gM})$ and $\mathrm{N}(\mathrm{gN})$, which are encoded by UL100 and UL73, respectively $[20,21] . \mathrm{gM} / \mathrm{gN}$ is the most abundant glycoprotein complex on virions $[22,23]$ and is essential in HCMV, as null mutants are non-viable. The $\mathrm{gM} / \mathrm{gN}$ complex plays key roles during attachment to host cells, likely by mediating interactions with heparan sulfate proteoglycans on the cell surface [24]. Notably, gM/gN also plays intracellular roles during viral replication that are independent of its roles in attachment $[25,26]$. gM is an $N$-glycosylated 48-kD type III transmembrane (TM) glycoprotein with seven predicted TM helices, while gN is a single-pass type I TM protein that is extensively $O$-glycosylated. The unmodified 138 amino acid gN polypeptide from strain AD169 specifies a molecular weight of approximately $18 \mathrm{kD}$ when expressed on its own; however, 
the fully glycosylated (mature) form detected from virion lysates migrates at $\sim 65-\mathrm{kD}$ in sodium dodecyl sulfate polyacrylamide gel electrophoresis (SDS-PAGE) [20,21]. Motifs in the gM cytoplasmic tail are required for trafficking during virion assembly [25], and the cytoplasmic tail of $\mathrm{gN}$, which is palmitoylated at two different cysteine residues, is required for secondary envelopment [26]. The gN coding sequence varies remarkably across HCMV strains [27,28], consistent with the observation that $\mathrm{gM} / \mathrm{gN}$ is an important target for humoral immune responses [29].

\section{The Trimeric gH/gL Complex and its Receptors}

gC-III, now frequently referred to as the "trimer" or "gH/gL/gO," is a heterotrimeric complex, in which the heterodimer of gH (UL75) and gL (UL115) is disulfide-linked to glycoprotein O (gO), a heavily $\mathrm{N}$-glycosylated polypeptide encoded by UL74 [30-32]. All herpesviruses encode $\mathrm{gH} / \mathrm{gL}$ complexes, as $\mathrm{gH} / \mathrm{gL}$ and $\mathrm{gB}$ together comprise the "core" herpesvirus membrane fusion machinery. Homologs of $\mathrm{gO}$, in contrast, are found only among betaherpesviruses. The emerging consensus is that $\mathrm{gO}$, in the context of trimer, is required for the infectivity of cell-free virions [33-35]. The platelet-derived growth factor receptor alpha (PDGFR $\alpha$ ) was identified in three independent studies to function as a cellular receptor for trimer [36-38] (Figure 1, Table 1). This finding has continued to find support in the literature [39,40], and the latest data suggest that tyrosine kinase activity of PDGFR $\alpha$ is dispensable for its role in HCMV entry [37,39].

The severe entry defects observed during infection of fibroblasts lacking PDGFR $\alpha$ phenocopy those seen with $g O$-null mutant viruses, with the residual low-level infectivity being pentamerdependent $[33,35,37-39]$. Thus, a role for PDGFR $\alpha$ in trimer-dependent entry may explain why gO is required for cell-free virions to infect fibroblasts, which ordinarily express PDGFR $\alpha$. Why gO is required for cell-free virions to infect epithelial or endothelial cells, however, remains unclear, since these cell types either do not express PDGFR $\alpha$ [37], or express it at only low levels that are not necessary for soluble recombinant trimer to bind to the cell surface [41]. Additional hitherto unidentified cellular receptors, or receptor-independent roles in membrane fusion, may explain why the trimer is required for cell-free virus to infect cells that lack PDGFR $\alpha$.

\section{The Pentameric gH/gL Complex and its Receptors}

In 2005, a second HCMV gH/gL complex, now often referred to as the "pentamer," was discovered after the repair of a frame-shift mutation in UL131 (UL131A) dramatically expanded the cell tropism of the fibroblast-adapted laboratory HCMV strain AD169, restoring its infectivity for epithelial and endothelial cells [42,43]. The pentamer is composed of the $\mathrm{gH} / \mathrm{gL}$ heterodimer bound to a trio of small glycoproteins encoded by UL128, UL130, and UL131 (also known as UL131A) [30,43-45]. The UL128-UL131 locus was observed to be: (i) unstable during HCMV passage in fibroblasts [46], and (ii) required for infection of leukocytes, dendritic cells, epithelial cells, and endothelial cells [47-50]. The latter observations may have hastened the discovery of the pentamer.

In 2015, a group from GSK Vaccines further defined the assembly of the pentamer. These investigators identified that the cysteine at amino acid position 144 (Cys144) of the gL polypeptide chain forms a disulfide bond to either UL128-Cys162 or gO-Cys351 [30]. These findings explain why the two $\mathrm{gH} / \mathrm{gL}$ complexes are mutually exclusive. The same study also provided low-resolution EM images of recombinant pentamer and trimer bound to $\mathrm{gH}$ antibodies. A subsequent study characterized neutralizing antibody binding sites using similar approaches [51].

In 2017, X-ray crystal structures for the pentamer bound to two different neutralizing antibodies were reported at $3.0 \AA$ and $5.9 \AA$ [45]. Several aspects of the $\mathrm{gH}$ domain structure closely resemble Epstein-Barr virus (EBV) $\mathrm{gH}$, while the overall structure is nonetheless described as an intermediate between the "rod-like" conformation of herpes simplex virus-2 gH/gL, and the "boot-like" conformation of EBV gH/gL. Two disulfide bonds connect the N-termini of $\mathrm{gH}$ and gL to each other: gH-Cys59 to gL-Cys54, and gH-Cys95 to gL-Cys47. As predicted from the literature [46,47,52-55], UL128, UL130, and a C-terminal region of gL adopt chemokine folds: of the CC-type for gL and UL128, 
and of the C-type for UL130, which may suggest that the ancestral cytomegalovirus "pirated" host chemokine genes on multiple occasions. Integration of chemokines into the viral cell entry machinery may have provided receptor binding and signaling properties of immediate benefit to the virus, even if many of these features were later lost or extensively modified during evolution. Another striking aspect of the pentamer structure is how UL128 connects to gL. A $\sim 40$ amino acid region of UL128 (residues 123 to 162$)$ forms a surprisingly long $(\sim 50 \AA)$ flexible linker that stretches across UL130 and UL131 to reach gL, at which point the chain makes three alpha helical turns and presents Cys162 to form its disulfide linkage to Cys144 of gL [45]. It is fascinating to consider in what order the subunits of the pentamer must assemble for UL128 to adopt this peculiar final conformation.

Earlier this year, neuropilin-2 (Nrp2) was convincingly identified as a functional cell entry receptor for the pentamer [40] (Figure 1, Table 1). To identify Nrp2, the investigators made use of a high-throughput "avidity-based extracellular interaction screen" (AVEXIS), in which recombinant single-pass transmembrane proteins were monitored in vitro for interactions with recombinant trimer and pentamer. After identifying a high-affinity interaction between Nrp2 and the pentamer, the investigators demonstrated that Nrp2 is essential for pentamer-dependent HCMV infection of endothelial and epithelial cells. The screen also identified interactions with other cellular molecules that may represent additional receptors. For trimer, the additional hits included transforming growth factor beta receptor type 3 (TGF $\beta$ RIII) and neuregulin-2 (NRG2). For pentamer, the additional high-affinity interaction hits were thrombomodulin (THBD), leukocyte immunoglobulin-like receptor subfamily B member 3 (LILRB3), and the immunoglobulin alpha Fc receptor (FCAR). Another hit for the pentamer, though of lower affinity, was CD46. Although the biological relevance for these other hits remains to be established, it seems likely that at least some of these molecules will turn out to play roles during natural infection.

\section{Additional Receptors}

CD147 was recently shown to be required for pentamer-dependent entry into epithelial cells in a manner that does not involve a direct interaction with the pentamer [56] (Figure 1, Table 1). Lujo virus, an arenavirus, requires Nrp2 as a surface receptor, and also requires CD63, a tetraspannin protein, as an intracellular factor for entry [57]. Notably, another tetraspannin, CD151, was also recently reported to play roles during HCMV entry [58]. By analogy, it seems plausible that Nrp2 functions as the proximal cell surface receptor for the pentamer, while other molecules, such as CD147 or CD151, function later as co-receptors, perhaps at a post-internalization step.

Another cellular molecule recently implicated as an HCMV receptor is THY-1 (CD90), which reportedly interacts with both $\mathrm{gH}$ and $\mathrm{gB}[59,60]$. THY- 1 engages $\alpha \mathrm{V} \beta 3$ integrins and recruits the signaling adaptor molecule paxillin during signaling. The $\alpha \mathrm{V} \beta 3$ integrins reportedly function as gH-dependent co-receptors [61], and paxillin has been found to be important during entry into monocytes [62]. Notably, integrins $\alpha 2, \alpha 6$, and $\beta 1$ are also reported to play roles during HCMV entry at a post-attachment step $[17,18]$. The interactions with integrins are thought to involve a "disintegrin-like" gB motif that resembles motifs found in the integrin-binding domain of cellular proteins of the "a disintegrin and a metalloproteinase" (ADAM) family. Nonetheless, the disintegrin-like motif is mostly buried in the post-fusion $\mathrm{gB}$ structure [13]. A high-resolution pre-fusion $\mathrm{gB}$ structure might help to shed further light on the role of this motif in entry.

\section{Many Are Called, Few Are Chosen?}

Over the years, many different cell surface proteins and molecules have been reported to function as HCMV entry receptors or otherwise contribute to viral entry ([15-18,24,36-40,56,58-61,63-70], Table 1). Considering the plethora of different cell types that the virus infects, it seems plausible that many if not all of these molecules play bona fide roles in early events during infection. That said, certain cell surface molecules likely function as the primary entry receptors that physically interact with viral glycoprotein complexes to drive default modes of entry. These default modes, of course, 
appear to differ between target cell types. PDGFR $\alpha$ can be considered a primary entry receptor for trimer-dependent infection of fibroblasts, since wild-type virus is profoundly defective for entry into fibroblasts under conditions in which PDGFR $\alpha$ is absent or unavailable, and pentamer-null virus shows a more severe, virtually absolute entry defect in these settings [36-39]. Nrp2, on the other hand, can be considered a primary entry receptor for pentamer-dependent infection of epithelial and endothelial cells, since HCMV fails to infect these cell types when soluble Nrp2 is present, or when Nrp2 is disrupted or knocked-down using small interfering RNA (siRNA) [40].

Table 1. Host cell surface factors implicated in human cytomegalovirus (HCMV) entry.

\begin{tabular}{ll}
\hline \multicolumn{1}{c}{ Host Cell Surface Entity } & \multicolumn{1}{c}{ References } \\
\hline Heparan sulfate proteoglycans (HSPG) & {$[17,24,63,64]$} \\
\hline Platelet-derived growth factor receptor alpha (PDGFR $\alpha)$ & {$[16,36-39,65]$} \\
\hline Neuropilin-2 (Nrp2) & {$[40]$} \\
\hline Epidermal growth factor receptor (EGFR) & {$[15,66-68]$} \\
\hline$\alpha$ V 33 integrin & {$[18,61,68]$} \\
\hline$\alpha 2 \beta 1$ integrin; $\alpha 6 \beta 1$ integrin & {$[17,18,68]$} \\
\hline$\alpha 1 \beta 1$ integrin; $\alpha 3 \beta 1$ integrin & {$[68]$} \\
\hline Major histocompatibility complex class I (MHC-I) & {$[69]$} \\
\hline CD13 (alanyl aminopeptidase) & {$[70]$} \\
\hline CD90 (THY-1) & {$[59,60]$} \\
\hline CD147 (Basigin) & {$[56]$} \\
\hline CD151 (MER2, RAPH, PETA-3) & {$[58]$} \\
\hline
\end{tabular}

Receptors and co-receptors for viral entry often function at steps that are temporally and spatially distinct from each other [71]. For instance, a given receptor may interact with a viral glycoprotein complex at the cell surface to promote endocytosis of virions, while another cellular factor may be required for membrane fusion and escape from the endocytic compartment. Thus, although the evidence for co-receptors is less straightforward, cellular factors other than Nrp2 and PDGFR $\alpha$ may turn out to be absolutely required for downstream events during entry. Meanwhile, other cellular molecules may serve in secondary roles, wherein any one of a number of different proteins could substitute to promote entry. Finally, there may turn out to be examples in which a cellular factor promotes entry but is not strictly necessary for infection to occur.

Of course, the cell type being infected has implications for the mechanistic details at play. Trimer-dependent entry into fibroblasts is rapid, does not require clathrin, and is $\mathrm{pH}$-independent, which led to the notion that this mode of entry involves fusion at plasma membrane [72,73] (Figure 1). According to the latest data, however, trimer-dependent entry into fibroblasts occurs through a rapid macropinocytosis [74]. Pentamer-dependent entry into epithelial and endothelial cells, on the other hand, requires low $\mathrm{pH}$, and presumably involves a more prolonged form of endocytosis [73]. Overall, the literature has made clear that pentamer and trimer drive entry into different cell types via distinct cell surface receptors, which strongly suggests that are at least two major modes of HCMV entry: pentamer-dependent and trimer-dependent [36,37,40,75] (Figure 1). Each mode likely involves a unique set of host proteins that play cell type-specific roles as receptors, co-receptors, or accessory factors that enhance infection. Further complicating matters, it may turn out that pentamer-dependent entry relies on distinct co-receptors in epithelial cells versus endothelial cells, even if Nrp2 is a primary entry receptor in both settings. 


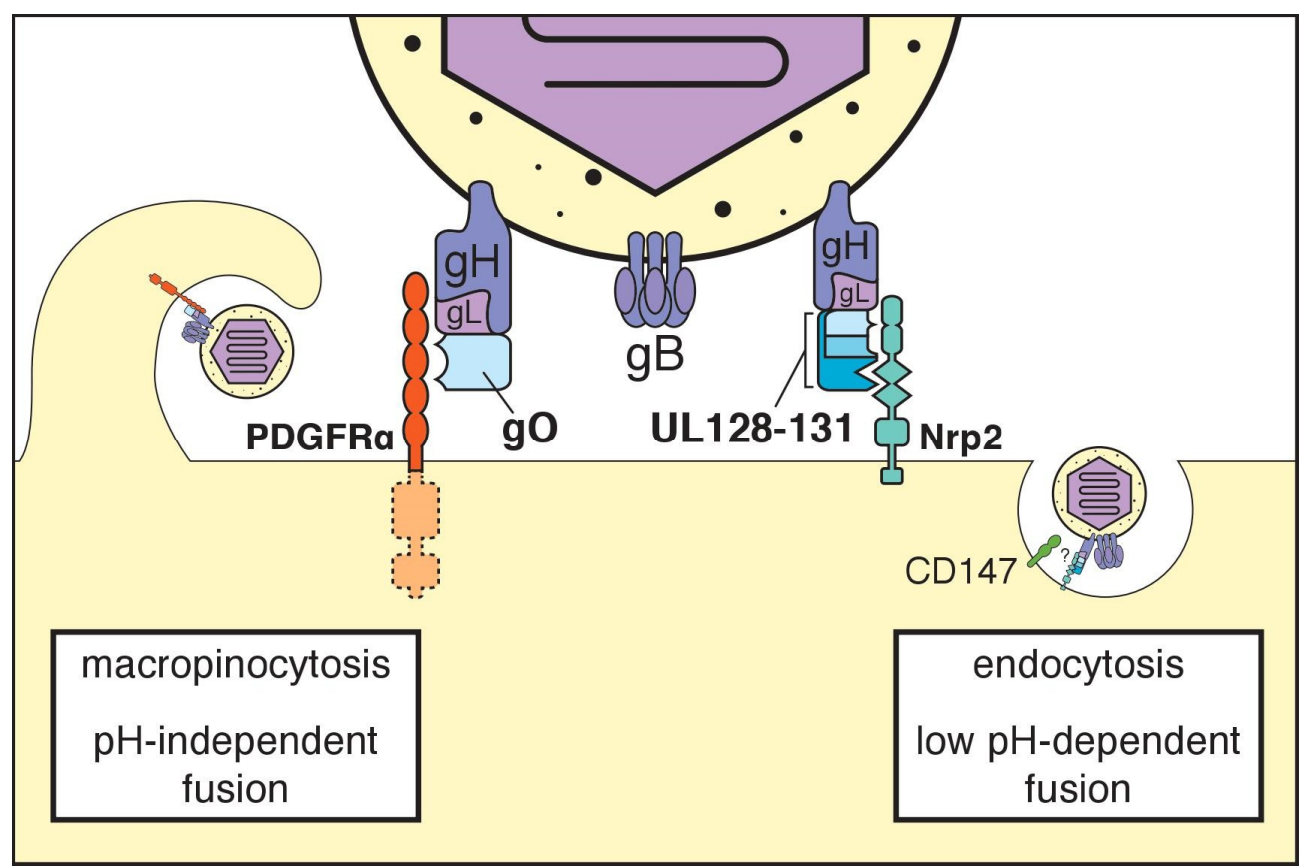

Figure 1. Receptors for HCMV gH/gL complexes. The trimeric gH/gL/gO complex (trimer) interacts with PDGFR $\alpha$ to drive a $\mathrm{pH}$-independent mode of entry that involves macropinocytosis. The pentameric $\mathrm{gH} / \mathrm{gL} / \mathrm{UL} 128-131$ complex (pentamer) interacts with Nrp2 in a mode of entry that involves endocytosis and a decrease in $\mathrm{pH}$. CD147 also appears to be required in the latter mode of entry. See text for additional details.

\section{How Do gH/gL Complexes Regulate Membrane Fusion?}

It is assumed that upon recognition of the appropriate cell surface receptor, $\mathrm{gH} / \mathrm{gL}$ complexes trigger $\mathrm{gB}$ to fuse virion and target cell membranes. Precisely how $\mathrm{gH} / \mathrm{gL}$ complexes regulate the $\mathrm{gB}$ fusogen is nevertheless unclear. Data suggesting a physical interaction between $\mathrm{gH} / \mathrm{gL}$ and $\mathrm{gB}$ come mainly from experiments with herpes simplex virus [76-78]. A recent HCMV study, however, reported co-immunoprecipitation (co-IP) results that suggest a stable complex between $\mathrm{gB}$ and $\mathrm{gH} / \mathrm{gL}$ occurs in infected cells and in virions [79]. Excitingly, a very recent cryo-ET study of HCMV strain AD169 virions further bolsters the possibility that $\mathrm{gH} / \mathrm{gL}$ and $\mathrm{gB}$ stably interact prior to fusion [14]. The study reports the in situ visualization of " $\mathrm{L}$ "-shaped densities that are interpreted to be $\mathrm{gH} / \mathrm{gL}$ complexes in contact with pre-fusion gB trimers in the virion envelope [14]. Although such complexes could be modeled only at $\sim 30 \AA$ A resolution, the authors were able to infer that domain I of gB may physically interact with $\mathrm{gH}$. Roughly $7 \%$ of the putative $\mathrm{gH} / \mathrm{gL}$ complexes appeared to contact pre-fusion $\mathrm{gB}$ homotrimers while no $\mathrm{gH} / \mathrm{gL}$ complexes were observed to contact post-fusion $\mathrm{gB}$. These findings are consistent with a model in which $\mathrm{gH} / \mathrm{gL}$ stabilizes the pre-fusion conformation of gB until receptor binding events trigger the transition to the post-fusion state, which presumably drives membrane fusion events.

Since the trimer is strongly required for the infectivity of cell-free HCMV virions in all cell types, it has been argued that pentamer may stimulate endocytosis of virions, while actual membrane fusion events may require the trimer to activate gB [34]. Other authors argue that the trimer mediates interactions with cell surface molecules to promote virion uptake via macropinocytosis, while the pentamer is required for escape from endosomes [41]. In the latter scenario, the pentamer would presumably act as an alternative fusion trigger for gB. One might hypothesize that interactions with PDGFR $\alpha$ are required for the trimer to function as a fusion trigger for $\mathrm{gB}$, and that in the absence of PDGFR $\alpha$, the trimer promotes endocytosis but not membrane fusion. Future studies leveraging structural, biophysical, and cell biology-based approaches will be needed to illustrate how $\mathrm{gB}$ is regulated during pentamer/Nrp2-dependent versus trimer/PDGFR $\alpha$-dependent modes of entry. 


\section{Cell-Associated versus Cell Free Spread}

HCMV is thought to disseminate within the host primarily through direct cell-to-cell spread rather than via the release of extracellular (cell-free) virions, which would be susceptible to antibody responses. Most of the infectious virus in the blood of seropositive and acutely infected patients is found in the leukocyte compartment, rather than in plasma or serum [80-82]. Furthermore, clinical isolates of HCMV spread in a highly cell-associated manner during initial tissue culture passages [83,84], and the progressive loss of this cell-associated phenotype correlates with disruption of several elements within the viral genome $[83,85]$. Below, we consider some examples of viral genes that have been implicated to impact cell-associated versus cell-free spread.

\subsection{RL13}

$R L 13$, which encodes a virion envelope glycoprotein, is among the viral genes that most rapidly mutate during tissue culture propagation of the virus, often acquiring nonsense or frameshift mutations after one to four passages on fibroblasts, endothelial cells, or epithelial cells [85,86]. Cultured fibroblasts infected with HCMV harboring repaired RL13 and UL128-UL131 loci produce remarkably small amounts of cell-free infectious virus until several weeks post-infection $[85,86]$. These observations may suggest that RL13 functions to dampen HCMV spread in vivo, perhaps to promote long-term persistence. Alternatively, these findings may reflect selection pressures peculiar to laboratory cultivation of the virus under tissue culture conditions. Unfortunately, little is known about the function of RL13. Ectopically expressed RL13 has been shown to traffic to the cell surface and bind the $\mathrm{F}_{\mathrm{C}}$ domain of $\operatorname{IgG}_{1}$ and $\mathrm{IgG}_{2}$ antibodies, followed by internalization [87]. These findings may imply an immune-evasive function for RL13, though RL13-dependent internalization of IgG has not yet been demonstrated in the context of the infected cell. RL13 has also been shown to strongly suppress the contribution of gO to cell-free spread in a UL128-null strain Merlin background [88]. Although these findings shed light on interactions of RL13 with cellular and viral factors, they do not readily explain why RL13 is unstable during tissue culture propagation of HCMV.

\section{2. gH/gL Complexes and Cell Tropism}

The literature suggests that cell-free versus cell-associated modes of spread are governed in large part by the composition of $\mathrm{gH} / \mathrm{gL}$ complexes expressed in the virion envelope. Restoration of pentamer expression increases the cell-associated nature of the virus [48], and a more recent study showed that the pentamer drives a mode of direct cell-to-cell spread that resists antibody neutralization [89]. Accordingly, repair of the pentamer in strain AD169 promotes the formation of syncytia during in vitro cultivation of the virus [42]. On the other hand, the trimer is required for the infectivity of cell-free virions [33,35]. Although one might assert that the pentamer promotes cell-associated modes of spread while the trimer enhances cell-free spread, the pentamer is nonetheless required for cell-free virions to efficiently infect endothelial and epithelial cells as well as monocytes. Another observation that would confound generalizing the trimer and pentamer into respective "cell-free" versus "cell-to-cell spread" roles is that HCMV strain AD169 deleted for the essential tegument protein pp28 (UL99) was found to spread efficiently in cultured fibroblasts [90]. Because strain AD169 harbors a frameshift in UL131 that renders it unable to express pentamer, the efficient spread observed for the $p p 28$-null virus has led some to argue that the trimer may suffice to drive cell-to-cell spread in fibroblasts [39].

\subsection{Viral Genes and Polymorphisms that Impact HCMV Cell Tropism}

HCMV strains show large differences in the relative levels of pentamer and trimer incorporated into virions, and these differences correlate with cell tropism differences between strains [34,91]. A number of HCMV genes have the capacity to influence viral cell tropism at the stage of entry, and most of these presumably act via effects on the composition of $\mathrm{gH} / \mathrm{gL}$ complexes. Certain HCMV strains that maintain intact or largely intact $\mathrm{UL}^{\prime}{ }^{\prime}$ regions express the pentamer at low levels. Examples 
include viruses derived from infectious bacterial artificial chromosome (BAC) clones of strains TR [92], TB40/E [93], and VR1814/FIX [94]. These strains, at least when reconstituted on fibroblasts, express high levels of $\mathrm{gH} / \mathrm{gL} / \mathrm{gO}$ (trimer), and low levels of gH/gL/UL128-131 (pentamer). Although a mutation in an intron of UL128 has been identified to limit pentamer expression in strain TB40/E [95], why FIX and TR express similarly low levels of pentamer is unknown. Given their low levels of pentamer expression, it is perhaps unsurprising that these HCMV strains replicate inefficiently on epithelial cells [42]. On the other hand, the highly passaged strain AD169, which carries a ULb' region that has undergone rearrangements and deletions leading to loss of $\sim 14 \mathrm{kbp}$ of coding content [96], replicates robustly on epithelial cells when pentamer expression is restored [42].

Intriguingly, ablation of UL148, a gene within the $\mathrm{UL}^{\prime}$, enhances the ability of strain TB40/E to replicate to high levels in ARPE-19 epithelial cells, and leads to a striking reduction in overall levels of $\mathrm{gH} / \mathrm{gL}$ and of trimer in virions $([97,98])$ (Figure 2). The UL148-null phenotype is accompanied by a markedly reduced expression of gO, which likely explains why UL148-null mutants express low levels of trimer. Nonetheless, the increase in epithelial cell tropism does not appear to involve enhanced pentamer expression.

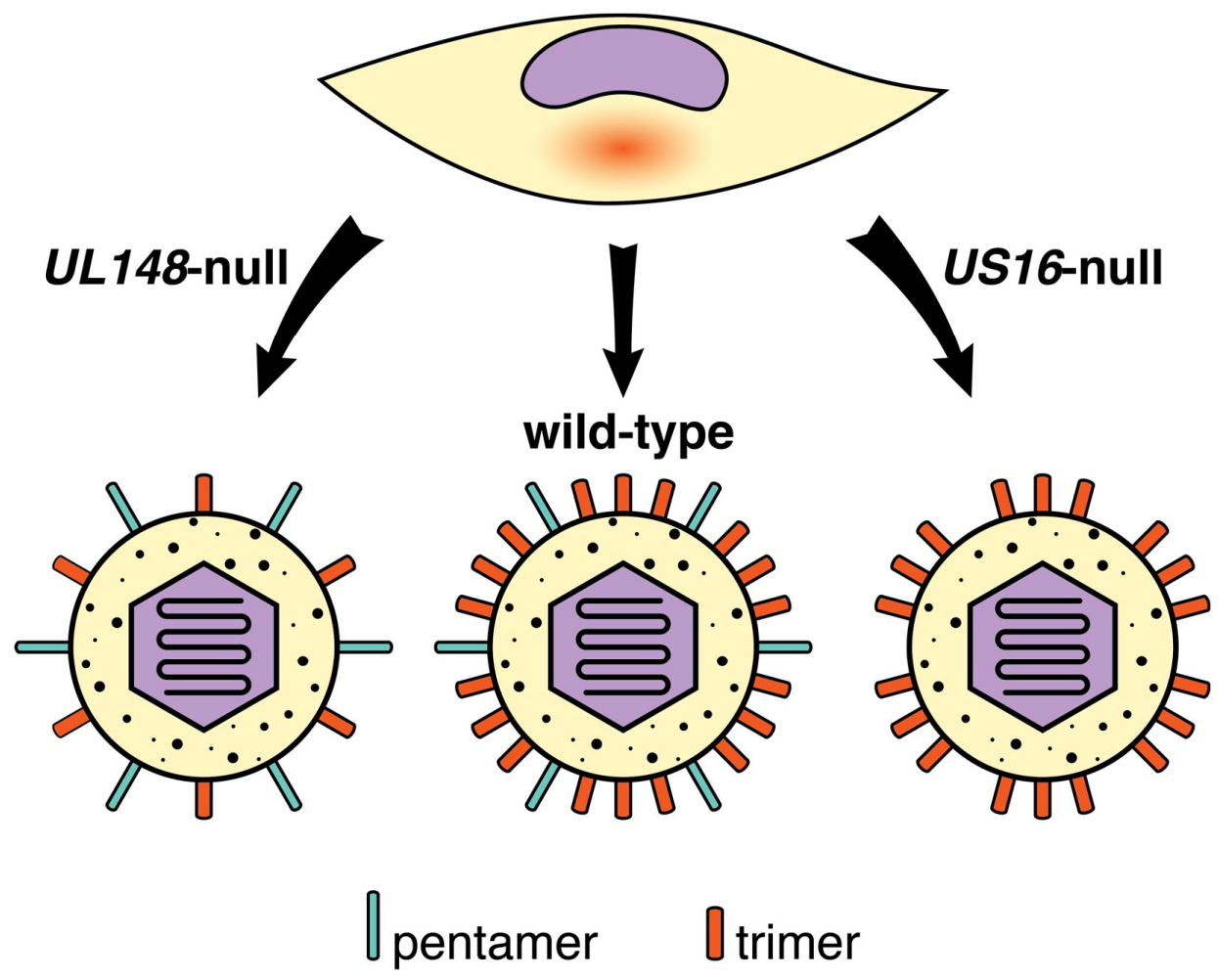

Figure 2. Regulation of alternative gH/gL complexes by UL148 and US16. UL148, a viral endoplasmic reticulum (ER)-resident glycoprotein, promotes high-level expression of the trimer during infection (wild-type) by stabilizing gO within the endoplasmic reticulum, resulting in the production of trimer-rich progeny virions. In UL148-null infections, decreased levels of trimer are synthesized, leading to the production of virions that more efficiently infect and spread between epithelial cells. US16, in contrast, localizes to the viral assembly compartment to promote incorporation of the pentamer into progeny virions, perhaps via physical interaction with UL130. US16-null mutants produce progeny virions lacking pentamer that are unable to infect endothelial and epithelial cells. See text for additional details.

We recently reported that newly synthesized $\mathrm{gO}$, but not other glycoproteins, is constitutively targeted for ER-associated degradation (ERAD) during infection [98]. UL148 appears to reduce the rate at which $\mathrm{gO}$ is degraded, possibly by interacting with SEL1L, a core component of the ERAD machinery. The observation that $\mathrm{gO}$ behaves as a constitutive ERAD substrate suggests that modulation 
of ERAD could provide a platform for viral regulation of cell tropism in HCMV and perhaps other betaherpesviruses. Nonetheless, whether UL148 is somehow regulated to stabilize gO in a cell-type specific manner remains to be seen. Interestingly, UL148 was also recently identified to prevent surface presentation of CD58 (LFA-3), a co-stimulatory ligand for natural killer cells and T-cells [99], and to strongly contribute to the induction of the unfolded protein response (UPR) during infection [100]. It is not yet clear how the roles of UL148 in CD58 retention or gO stabilization relate to its activation of the UPR. However, pharmacologic and siRNA treatments that inhibit or deplete the ERAD machinery stabilize gO expression [98]. Since blockade of ERAD would also be expected to activate the UPR, it seems reasonable to hypothesize that UL148 functions in part by inhibiting ERAD.

US16 is another viral factor that was recently identified to impact the composition of $\mathrm{gH} / \mathrm{gL}$ complexes in HCMV virions [101]. US16-null mutant viruses fail to incorporate pentamer into progeny virions and accordingly are unable to efficiently infect epithelial cells or endothelial cells. Unlike UL148, which resides in the ER, US16 localizes to the cytoplasmic viral assembly compartment (cVAC), where virions acquire their infectious envelopes. How US16 promotes pentamer incorporation is unclear, but co-immunoprecipitation results suggest that US16 interacts with the pentamer subunit UL130. The observation that US16 localizes to-and presumably functions at-the cVAC may suggest that the trans-Golgi network-derived vesicles which provide virion envelopes are heterogeneous. Alternatively, US16 may negatively regulate degradation of pentamer by cVAC-associated lysosomes, or otherwise promote incorporation of the pentamer into virions.

It is intriguing to speculate that gene products such as US16 and UL148 could play tissue-specific roles in modulating the composition of viral $\mathrm{gH} / \mathrm{gL}$ complexes in vivo. The relative expression levels of pentamer and trimer may influence whether HCMV infection spreads in a cell-associated, antibody-resistant manner, or via cell-free particles, as would be more compatible with horizontal transmission via body fluids. It thus seems crucial to identify how viral modulators of the alternative $\mathrm{gH} / \mathrm{gL}$ complexes might themselves be regulated. Of course, it would be helpful to know in the first place whether virions shed in saliva, urine, or breast milk contain higher levels of trimer than those produced for intra-host spread.

In the example of EBV, a viral tropism switch that drives alternating cycles of viral replication between B-cells and epithelial cells depends on the cell type producing virus to regulate the levels in of $\mathrm{gH} / \mathrm{gL}$ and $\mathrm{gH} / \mathrm{gL} / \mathrm{gp} 42$ in progeny virions, with the gp42 containing complex being required for infection of B-cells [102]. Although the cell tropism of fibroblast-derived HCMV virions is reportedly more heterogeneous than that of virions produced from endothelial cells [2], additional research in this area is certainly warranted. Regardless, should a tropism switch exist in HCMV, one might expect the mechanisms to differ substantially from those found in EBV.

\section{What Can We Infer from Cytomegaloviruses of Rodents and Nonhuman Primates?}

A large number of CMVs co-speciated with their hosts during the mammalian radiation, which occurred approximately 60 to 80 million ago [103]. Accordingly, rodent and primate CMVs are studied in the context of their natural hosts to model myriad aspects of HCMV biology and pathogenesis [104-109], as well as to evaluate the potential use of HCMV as a vaccine vector [110,111]. Even though primate and rodent CMVs share many features, including their tropism for the salivary gland [112,113], the extent to which viral entry and host navigation are conserved remains largely unknown. Although CMVs are thought to enter new hosts either via the oral cavity (ingestion) or via the nasal route (inhalation), the recent literature suggests that MCMV strongly relies on the nasal route to establish infection [114]. Following intranasal infection of mouse pups, a $g O$-null MCMV mutant was unable to colonize the salivary gland, suggesting that systemic spread depends on gO [115]. Furthermore, these defects were associated with an impaired ability of the $g O$-null virus to infect epithelial cells [115]. In contrast, a $g O$-null virus was observed to readily colonize the salivary gland in immunocompromised BALB/C mice infected intraperitoneally [116]. Therefore, the route of infection may have strong effects on tissue tropism phenotypes. 
Given that millions of years have elapsed since the ancestral cytomegalovirus infected the common ancestor of tree shrews, rodents and primates [103,117], it is not surprising to find examples in which the extant CMVs have solved similar problems related to host colonization in different ways. For example, although HCMV and rhesus CMV (RhCMV) both encode ER-resident immuneëvasins that block cell surface presentation of natural killer cell activating ligands of the MIC and ULBP families, this function is carried out by UL16 in HCMV [118-120] but by Rh159 (the homolog of UL148) in RhCMV [121]. Nevertheless, the locus encoding $\mathrm{gO}$ (UL74) and gN (UL73), in which the residues encoding the C-termini of the encoded proteins overlap, is remarkably well-conserved across rodent and primate cytomegaloviruses $[86,92,122-126]$, as is the use of alternative gH/gL complexes. On the other hand, the HCMV UL $b^{\prime}$ region [96], which encodes pentamer components UL128-131, the putative tropism modulator UL148, and several other proteins with roles in persistence, differs substantially in rhesus CMV [127] and is virtually unrecognizable in rodent CMVs [122-124]. In mouse cytomegalovirus (MCMV), the alternative $\mathrm{gH} / \mathrm{gL}$ complexes identified thus far are both trimeric. One is comprised of $\mathrm{gH} / \mathrm{gL}$ bound to $\mathrm{gO}(\mathrm{m} 74)$ [128]; the other is made up of $\mathrm{gH} / \mathrm{gL}$ bound to MCK-2, a chemokine homolog [129]. RhCMV and guinea pig CMV (GPCMV), however, appear to make use of pentameric and trimeric $\mathrm{gH} / \mathrm{gL}$ complexes, and hence more closely resemble HCMV in this regard [127,130-134]. The two rat CMVs, which in fact represent distinct species [135], remain to be characterized for whether a pentameric complex or one akin to MCMV gH/gL/MCK-2 is expressed in virions [136].

Needless to say, it will be crucial to determine whether the animal orthologs of Nrp2 and PDGFR $\alpha$ function as entry receptors for the alternative $\mathrm{gH} / \mathrm{gL}$ complexes in CMVs of rodents and nonhuman primates. Should the underlying details for viral entry prove to be broadly conserved across the rodent and primate CMVs, this would further buttress the clinical relevance of the animal CMVs infection models.

\section{Conclusions and Outlook}

Although HCMV entry and host navigation remain to be fully understood, crucial new details concerning cellular receptors and the viral entry machinery have no doubt invigorated the field. It is hoped that the coming decade will see investigators leverage these advances to elucidate how gB-mediated membrane fusion events are regulated in response to interactions between viral glycoprotein complexes and their cognate cellular receptors, as well as to reveal how HCMV spreads throughout the host to reach sites relevant to persistence and horizontal shedding. Such information will be pivotal for the development of vaccines and therapies to combat the diseases caused by this fascinating opportunistic pathogen.

Acknowledgments: Research in the Kamil laboratory is supported by grants R01-AI116851, R01-AI143191, and P30-GM110703 from the National Institutes of Health. This content is solely the responsibility of the authors and does not necessarily represent the official views of the National Institutes of Health. C.C.N. is supported by a Malcolm Feist Fellowship in the Cardiovascular Sciences. The authors apologize to any researchers whose important contributions may have been unintentionally omitted in this review article.

Conflicts of Interest: J.P.K. is listed as a co-inventor on U.S. and international patent applications concerning UL148 and HCMV reactivation. The authors declare no other conflicts of interest. The funding agencies that support research in the Kamil laboratory had no role in the preparation of this review article.

\section{References}

1. Boeckh, M.; Geballe, A.P. Cytomegalovirus: Pathogen, paradigm, and puzzle. J. Clin. Investig. 2011, 121, 1673-1680. [CrossRef] [PubMed]

2. Scrivano, L.; Sinzger, C.; Nitschko, H.; Koszinowski, U.H.; Adler, B. HCMV spread and cell tropism are determined by distinct virus populations. PLoS Pathog. 2011, 7, e1001256. [CrossRef] [PubMed]

3. Chee, M.S.; Bankier, A.T.; Beck, S.; Bohni, R.; Brown, C.M.; Cerny, R.; Horsnell, T.; Hutchison, C.A., 3rd; Kouzarides, T.; Martignetti, J.A.; et al. Analysis of the protein-coding content of the sequence of human cytomegalovirus strain AD169. Curr. Top. Microbiol. Immunol. 1990, 154, 125-169. [PubMed] 
4. Britt, W.J. Neutralizing antibodies detect a disulfide-linked glycoprotein complex within the envelope of human cytomegalovirus. Virology 1984, 135, 369-378. [CrossRef]

5. Gretch, D.R.; Kari, B.; Rasmussen, L.; Gehrz, R.C.; Stinski, M.F. Identification and characterization of three distinct families of glycoprotein complexes in the envelopes of human cytomegalovirus. J. Virol. 1988, 62, 875-881.

6. Gretch, D.R.; Gehrz, R.C.; Stinski, M.F. Characterization of a human cytomegalovirus glycoprotein complex (gcI). J. Gen. Virol. 1988, 69 Pt 6, 1205-1215. [CrossRef]

7. Calo, S.; Cortese, M.; Ciferri, C.; Bruno, L.; Gerrein, R.; Benucci, B.; Monda, G.; Gentile, M.; Kessler, T.; Uematsu, Y.; et al. The Human Cytomegalovirus UL116 Gene Encodes an Envelope Glycoprotein Forming a Complex with gH Independently from gL. J. Virol. 2016, 90, 4926-4938. [CrossRef]

8. Heldwein, E.E.; Lou, H.; Bender, F.C.; Cohen, G.H.; Eisenberg, R.J.; Harrison, S.C. Crystal structure of glycoprotein B from herpes simplex virus 1. Science 2006, 313, 217-220. [CrossRef]

9. Chandramouli, S.; Ciferri, C.; Nikitin, P.A.; Calo, S.; Gerrein, R.; Balabanis, K.; Monroe, J.; Hebner, C.; Lilja, A.E.; Settembre, E.C.; et al. Structure of HCMV glycoprotein B in the postfusion conformation bound to a neutralizing human antibody. Nat. Commun. 2015, 6, 8176. [CrossRef]

10. Harrison, S.C. Viral membrane fusion. Virology 2015, 479-480, 498-507. [CrossRef]

11. Roche, S.; Albertini, A.A.; Lepault, J.; Bressanelli, S.; Gaudin, Y. Structures of vesicular stomatitis virus glycoprotein: Membrane fusion revisited. Cell. Mol. Life Sci. 2008, 65, 1716-1728. [CrossRef]

12. Britt, W.J.; Auger, D. Synthesis and processing of the envelope gp55-116 complex of human cytomegalovirus. J. Virol. 1986, 58, 185-191.

13. Burke, H.G.; Heldwein, E.E. Crystal Structure of the Human Cytomegalovirus Glycoprotein B. PLoS Pathog. 2015, 11, e1005227. [CrossRef]

14. Si, Z.; Zhang, J.; Shivakoti, S.; Atanasov, I.; Tao, C.L.; Hui, W.H.; Zhou, K.; Yu, X.; Li, W.; Luo, M.; et al. Different functional states of fusion protein $\mathrm{gB}$ revealed on human cytomegalovirus by cryo electron tomography with Volta phase plate. PLOS Pathog. 2018, 14, e1007452. [CrossRef]

15. Wang, X.; Huong, S.M.; Chiu, M.L.; Raab-Traub, N.; Huang, E.S. Epidermal growth factor receptor is a cellular receptor for human cytomegalovirus. Nature 2003, 424, 456-461. [CrossRef]

16. Soroceanu, L.; Akhavan, A.; Cobbs, C.S. Platelet-derived growth factor-alpha receptor activation is required for human cytomegalovirus infection. Nature 2008, 455, 391-395. [CrossRef]

17. Feire, A.L.; Roy, R.M.; Manley, K.; Compton, T. The glycoprotein B disintegrin-like domain binds beta 1 integrin to mediate cytomegalovirus entry. J. Virol. 2010, 84, 10026-10037. [CrossRef]

18. Feire, A.L.; Koss, H.; Compton, T. Cellular integrins function as entry receptors for human cytomegalovirus via a highly conserved disintegrin-like domain. Proc. Natl. Acad. Sci. USA 2004, 101, 15470-15475. [CrossRef]

19. Wille, P.T.; Wisner, T.W.; Ryckman, B.; Johnson, D.C. Human cytomegalovirus (HCMV) glycoprotein gB promotes virus entry in trans acting as the viral fusion protein rather than as a receptor-binding protein. mBio 2013, 4, e00332-13. [CrossRef]

20. Mach, M.; Kropff, B.; Dal Monte, P.; Britt, W. Complex formation by human cytomegalovirus glycoproteins M (gpUL100) and N (gpUL73). J. Virol. 2000, 74, 11881-11892. [CrossRef]

21. Mach, M.; Kropff, B.; Kryzaniak, M.; Britt, W. Complex formation by glycoproteins M and N of human cytomegalovirus: Structural and functional aspects. J. Virol. 2005, 79, 2160-2170. [CrossRef]

22. Kropff, B.; Burkhardt, C.; Schott, J.; Nentwich, J.; Fisch, T.; Britt, W.; Mach, M. Glycoprotein N of human cytomegalovirus protects the virus from neutralizing antibodies. PLoS Pathog. 2012, 8, e1002999. [CrossRef]

23. Varnum, S.M.; Streblow, D.N.; Monroe, M.E.; Smith, P.; Auberry, K.J.; Pasa-Tolic, L.; Wang, D.; Camp, D.G., 2nd; Rodland, K.; Wiley, S.; et al. Identification of proteins in human cytomegalovirus (HCMV) particles: The HCMV proteome. J. Virol. 2004, 78, 10960-10966. [CrossRef]

24. Kari, B.; Gehrz, R. A human cytomegalovirus glycoprotein complex designated gC-II is a major heparin-binding component of the envelope. J. Virol. 1992, 66, 1761-1764.

25. Krzyzaniak, M.; Mach, M.; Britt, W.J. The cytoplasmic tail of glycoprotein M (gpUL100) expresses trafficking signals required for human cytomegalovirus assembly and replication. J. Virol. 2007, 81, 10316-10328. [CrossRef]

26. Mach, M.; Osinski, K.; Kropff, B.; Schloetzer-Schrehardt, U.; Krzyzaniak, M.; Britt, W. The carboxy-terminal domain of glycoprotein $\mathrm{N}$ of human cytomegalovirus is required for virion morphogenesis. J. Virol. 2007, 81, 5212-5224. [CrossRef] 
27. Renzette, N.; Bhattacharjee, B.; Jensen, J.D.; Gibson, L.; Kowalik, T.F. Extensive genome-wide variability of human cytomegalovirus in congenitally infected infants. PLoS Pathog. 2011, 7, e1001344. [CrossRef]

28. Pignatelli, S.; Dal Monte, P.; Rossini, G.; Chou, S.; Gojobori, T.; Hanada, K.; Guo, J.J.; Rawlinson, W.; Britt, W.; Mach, M.; et al. Human cytomegalovirus glycoprotein N (gpUL73-gN) genomic variants: Identification of a novel subgroup, geographical distribution and evidence of positive selective pressure. J. Gen. Virol. 2003, 84, 647-655. [CrossRef]

29. Shimamura, M.; Mach, M.; Britt, W.J. Human cytomegalovirus infection elicits a glycoprotein M (gM)/gN-specific virus-neutralizing antibody response. J. Virol. 2006, 80, 4591-4600. [CrossRef]

30. Ciferri, C.; Chandramouli, S.; Donnarumma, D.; Nikitin, P.A.; Cianfrocco, M.A.; Gerrein, R.; Feire, A.L.; Barnett, S.W.; Lilja, A.E.; Rappuoli, R.; et al. Structural and biochemical studies of HCMV gH/gL/gO and Pentamer reveal mutually exclusive cell entry complexes. Proc. Natl. Acad. Sci. USA 2015, 112, 1767-1772. [CrossRef]

31. Huber, M.T.; Compton, T. Characterization of a novel third member of the human cytomegalovirus glycoprotein H-glycoprotein L complex. J. Virol. 1997, 71, 5391-5398.

32. Huber, M.T.; Compton, T. The human cytomegalovirus UL74 gene encodes the third component of the glycoprotein H-glycoprotein L-containing envelope complex. J. Virol. 1998, 72, 8191-8197.

33. Jiang, X.J.; Adler, B.; Sampaio, K.L.; Digel, M.; Jahn, G.; Ettischer, N.; Stierhof, Y.D.; Scrivano, L.; Koszinowski, U.; Mach, M.; et al. UL74 of human cytomegalovirus contributes to virus release by promoting secondary envelopment of virions. J. Virol. 2008, 82, 2802-2812. [CrossRef]

34. Zhou, M.; Lanchy, J.M.; Ryckman, B.J. Human Cytomegalovirus gH/gL/gO Promotes the Fusion Step of Entry into All Cell Types, whereas gH/gL/UL128-131 Broadens Virus Tropism through a Distinct Mechanism. J. Virol. 2015, 89, 8999-9009. [CrossRef]

35. Wille, P.T.; Knoche, A.J.; Nelson, J.A.; Jarvis, M.A.; Johnson, D.C. A human cytomegalovirus gO-null mutant fails to incorporate $\mathrm{gH} / \mathrm{gL}$ into the virion envelope and is unable to enter fibroblasts and epithelial and endothelial cells. J. Virol. 2010, 84, 2585-2596. [CrossRef]

36. Kabanova, A.; Marcandalli, J.; Zhou, T.; Bianchi, S.; Baxa, U.; Tsybovsky, Y.; Lilleri, D.; Silacci-Fregni, C.; Foglierini, M.; Fernandez-Rodriguez, B.M.; et al. Platelet-derived growth factor-alpha receptor is the cellular receptor for human cytomegalovirus gHgLgO trimer. Nat. Microbiol. 2016, 1, 16082. [CrossRef]

37. Wu, Y.; Prager, A.; Boos, S.; Resch, M.; Brizic, I.; Mach, M.; Wildner, S.; Scrivano, L.; Adler, B. Human cytomegalovirus glycoprotein complex gH/gL/gO uses PDGFR-alpha as a key for entry. PLoS Pathog. 2017, 13, e1006281. [CrossRef]

38. Stegmann, C.; Hochdorfer, D.; Lieber, D.; Subramanian, N.; Stohr, D.; Laib Sampaio, K.; Sinzger, C. A derivative of platelet-derived growth factor receptor alpha binds to the trimer of human cytomegalovirus and inhibits entry into fibroblasts and endothelial cells. PLoS Pathog. 2017, 13, e1006273. [CrossRef]

39. Wu, K.; Oberstein, A.; Wang, W.; Shenk, T. Role of PDGF receptor-alpha during human cytomegalovirus entry into fibroblasts. Proc. Natl. Acad. Sci. USA 2018, 115, E9889-E9898. [CrossRef]

40. Martinez-Martin, N.; Marcandalli, J.; Huang, C.S.; Arthur, C.P.; Perotti, M.; Foglierini, M.; Ho, H.; Dosey, A.M.; Shriver, S.; Payandeh, J.; et al. An Unbiased Screen for Human Cytomegalovirus Identifies Neuropilin-2 as a Central Viral Receptor. Cell 2018, 174, 1158-1171. [CrossRef]

41. Liu, J.; Jardetzky, T.S.; Chin, A.L.; Johnson, D.C.; Vanarsdall, A.L. The human cytomegalovirus trimer and pentamer promote sequential steps in entry into epithelial and endothelial cells at cell surfaces and endosomes. J. Virol. 2018. [CrossRef]

42. Wang, D.; Shenk, T. Human cytomegalovirus UL131 open reading frame is required for epithelial cell tropism. J. Virol. 2005, 79, 10330-10338. [CrossRef]

43. Wang, D.; Shenk, T. Human cytomegalovirus virion protein complex required for epithelial and endothelial cell tropism. Proc. Natl. Acad. Sci. USA 2005, 102, 18153-18158. [CrossRef]

44. Ryckman, B.J.; Rainish, B.L.; Chase, M.C.; Borton, J.A.; Nelson, J.A.; Jarvis, M.A.; Johnson, D.C. Characterization of the human cytomegalovirus $\mathrm{gH} / \mathrm{gL} / \mathrm{UL} 128-131$ complex that mediates entry into epithelial and endothelial cells. J. Virol. 2008, 82, 60-70. [CrossRef]

45. Chandramouli, S.; Malito, E.; Nguyen, T.; Luisi, K.; Donnarumma, D.; Xing, Y.; Norais, N.; Yu, D.; Carfi, A. Structural basis for potent antibody-mediated neutralization of human cytomegalovirus. Sci. Immunol. 2017, 2, eaan1457. [CrossRef] 
46. Akter, P.; Cunningham, C.; McSharry, B.P.; Dolan, A.; Addison, C.; Dargan, D.J.; Hassan-Walker, A.F.; Emery, V.C.; Griffiths, P.D.; Wilkinson, G.W.; et al. Two novel spliced genes in human cytomegalovirus. J. Gen. Virol. 2003, 84, 1117-1122. [CrossRef]

47. Hahn, G.; Revello, M.G.; Patrone, M.; Percivalle, E.; Campanini, G.; Sarasini, A.; Wagner, M.; Gallina, A.; Milanesi, G.; Koszinowski, U.; et al. Human cytomegalovirus UL131-128 genes are indispensable for virus growth in endothelial cells and virus transfer to leukocytes. J. Virol. 2004, 78, 10023-10033. [CrossRef]

48. Adler, B.; Scrivano, L.; Ruzcics, Z.; Rupp, B.; Sinzger, C.; Koszinowski, U. Role of human cytomegalovirus UL131A in cell type-specific virus entry and release. J. Gen. Virol. 2006, 87, 2451-2460. [CrossRef]

49. Patrone, M.; Secchi, M.; Fiorina, L.; Ierardi, M.; Milanesi, G.; Gallina, A. Human cytomegalovirus UL130 protein promotes endothelial cell infection through a producer cell modification of the virion. J. Virol. 2005, 79, 8361-8373. [CrossRef]

50. Gerna, G.; Percivalle, E.; Lilleri, D.; Lozza, L.; Fornara, C.; Hahn, G.; Baldanti, F.; Revello, M.G. Dendritic-cell infection by human cytomegalovirus is restricted to strains carrying functional UL131-128 genes and mediates efficient viral antigen presentation to CD8+ T cells. J. Gen. Virol. 2005, 86, 275-284. [CrossRef]

51. Ciferri, C.; Chandramouli, S.; Leitner, A.; Donnarumma, D.; Cianfrocco, M.A.; Gerrein, R.; Friedrich, K.; Aggarwal, Y.; Palladino, G.; Aebersold, R.; et al. Antigenic Characterization of the HCMV gH/gL/gO and Pentamer Cell Entry Complexes Reveals Binding Sites for Potently Neutralizing Human Antibodies. PLoS Pathog. 2015, 11, e1005230. [CrossRef] [PubMed]

52. Malkowska, M.; Kokoszynska, K.; Dymecka, M.; Rychlewski, L.; Wyrwicz, L.S. Alphaherpesvirinae and Gammaherpesvirinae glycoprotein L and CMV UL130 originate from chemokines. Virol J. 2013, 10, 1. [CrossRef] [PubMed]

53. Stampfer, S.D.; Heldwein, E.E. Stuck in the middle: Structural insights into the role of the gH/gL heterodimer in herpesvirus entry. Curr. Opin. Virol. 2013, 3, 13-19. [CrossRef]

54. Baldanti, F.; Paolucci, S.; Campanini, G.; Sarasini, A.; Percivalle, E.; Revello, M.G.; Gerna, G. Human cytomegalovirus UL131A, UL130 and UL128 genes are highly conserved among field isolates. Arch. Virol. 2006, 151, 1225-1233. [CrossRef] [PubMed]

55. Novotny, J.; Rigoutsos, I.; Coleman, D.; Shenk, T. In silico structural and functional analysis of the human cytomegalovirus (HHV5) genome. J. Mol. Biol. 2001, 310, 1151-1166. [CrossRef]

56. Vanarsdall, A.L.; Pritchard, S.R.; Wisner, T.W.; Liu, J.; Jardetzky, T.S.; Johnson, D.C. CD147 Promotes Entry of Pentamer-Expressing Human Cytomegalovirus into Epithelial and Endothelial Cells. mBio 2018, 9, e00781-18. [CrossRef] [PubMed]

57. Raaben, M.; Jae, L.T.; Herbert, A.S.; Kuehne, A.I.; Stubbs, S.H.; Chou, Y.Y.; Blomen, V.A.; Kirchhausen, T.; Dye, J.M.; Brummelkamp, T.R.; et al. NRP2 and CD63 Are Host Factors for Lujo Virus Cell Entry. Cell Host Microbe 2017, 22, 688-696. [CrossRef] [PubMed]

58. Hochdorfer, D.; Florin, L.; Sinzger, C.; Lieber, D. Tetraspanin CD151 Promotes Initial Events in Human Cytomegalovirus Infection. J. Virol. 2016, 90, 6430-6442. [CrossRef]

59. Li, Q.; Wilkie, A.R.; Weller, M.; Liu, X.; Cohen, J.I. THY-1 Cell Surface Antigen (CD90) Has an Important Role in the Initial Stage of Human Cytomegalovirus Infection. PLoS Pathog. 2015, 11, e1004999. [CrossRef] [PubMed]

60. Li, Q.; Fischer, E.; Cohen, J.I. Cell Surface THY-1 Contributes to Human Cytomegalovirus Entry via a Macropinocytosis-Like Process. J. Virol. 2016, 90, 9766-9781. [CrossRef] [PubMed]

61. Wang, X.; Huang, D.Y.; Huong, S.M.; Huang, E.S. Integrin alphavbeta3 is a coreceptor for human cytomegalovirus. Nat. Med. 2005, 11, 515-521. [CrossRef] [PubMed]

62. Nogalski, M.T.; Chan, G.; Stevenson, E.V.; Gray, S.; Yurochko, A.D. Human cytomegalovirus-regulated paxillin in monocytes links cellular pathogenic motility to the process of viral entry. J. Virol. 2011, 85, 1360-1369. [CrossRef] [PubMed]

63. Carlson, C.; Britt, W.J.; Compton, T. Expression, purification, and characterization of a soluble form of human cytomegalovirus glycoprotein B. Virology 1997, 239, 198-205. [CrossRef] [PubMed]

64. Compton, T.; Nowlin, D.M.; Cooper, N.R. Initiation of human cytomegalovirus infection requires initial interaction with cell surface heparan sulfate. Virology 1993, 193, 834-841. [CrossRef] [PubMed]

65. Vanarsdall, A.L.; Wisner, T.W.; Lei, H.; Kazlauskas, A.; Johnson, D.C. PDGF receptor-alpha does not promote HCMV entry into epithelial and endothelial cells but increased quantities stimulate entry by an abnormal pathway. PLoS Pathog. 2012, 8, e1002905. [CrossRef] [PubMed] 
66. Chan, G.; Nogalski, M.T.; Yurochko, A.D. Activation of EGFR on monocytes is required for human cytomegalovirus entry and mediates cellular motility. Proc. Natl. Acad. Sci. USA 2009, 106, 22369-22374. [CrossRef] [PubMed]

67. Kim, J.H.; Collins-McMillen, D.; Buehler, J.C.; Goodrum, F.D.; Yurochko, A.D. Human Cytomegalovirus Requires Epidermal Growth Factor Receptor Signaling To Enter and Initiate the Early Steps in the Establishment of Latency in CD34(+) Human Progenitor Cells. J. Virol. 2017, 91, e01206-16. [CrossRef] [PubMed]

68. Maidji, E.; Genbacev, O.; Chang, H.T.; Pereira, L. Developmental regulation of human cytomegalovirus receptors in cytotrophoblasts correlates with distinct replication sites in the placenta. J. Virol. 2007, 81, 4701-4712. [CrossRef] [PubMed]

69. Grundy, J.E.; McKeating, J.A.; Ward, P.J.; Sanderson, A.R.; Griffiths, P.D. Beta 2 microglobulin enhances the infectivity of cytomegalovirus and when bound to the virus enables class I HLA molecules to be used as a virus receptor. J. Gen. Virol. 1987, 68 Pt 3, 793-803. [CrossRef]

70. Soderberg, C.; Giugni, T.D.; Zaia, J.A.; Larsson, S.; Wahlberg, J.M.; Moller, E. CD13 (human aminopeptidase N) mediates human cytomegalovirus infection. J. Virol. 1993, 67, 6576-6585. [PubMed]

71. Grove, J.; Marsh, M. The cell biology of receptor-mediated virus entry. J. Cell Biol. 2011, 195, 1071-1082. [CrossRef] [PubMed]

72. Compton, T.; Nepomuceno, R.R.; Nowlin, D.M. Human cytomegalovirus penetrates host cells by $\mathrm{pH}$-independent fusion at the cell surface. Virology 1992, 191, 387-395. [CrossRef]

73. Ryckman, B.J.; Jarvis, M.A.; Drummond, D.D.; Nelson, J.A.; Johnson, D.C. Human cytomegalovirus entry into epithelial and endothelial cells depends on genes UL128 to UL150 and occurs by endocytosis and low-pH fusion. J. Virol. 2006, 80, 710-722. [CrossRef] [PubMed]

74. Hetzenecker, S.; Helenius, A.; Krzyzaniak, M.A. HCMV Induces Macropinocytosis for Host Cell Entry in Fibroblasts. Traffic 2016, 17, 351-368. [CrossRef] [PubMed]

75. Nogalski, M.T.; Chan, G.C.; Stevenson, E.V.; Collins-McMillen, D.K.; Yurochko, A.D. The HCMV $\mathrm{gH} / \mathrm{gL} / \mathrm{UL} 128-131$ complex triggers the specific cellular activation required for efficient viral internalization into target monocytes. PLoS Pathog. 2013, 9, e1003463. [CrossRef] [PubMed]

76. Atanasiu, D.; Whitbeck, J.C.; de Leon, M.P.; Lou, H.; Hannah, B.P.; Cohen, G.H.; Eisenberg, R.J. Bimolecular complementation defines functional regions of Herpes simplex virus $\mathrm{gB}$ that are involved with $\mathrm{gH} / \mathrm{gL}$ as a necessary step leading to cell fusion. J. Virol. 2010, 84, 3825-3834. [CrossRef] [PubMed]

77. Avitabile, E.; Forghieri, C.; Campadelli-Fiume, G. Complexes between herpes simplex virus glycoproteins $\mathrm{gD}, \mathrm{gB}$, and $\mathrm{gH}$ detected in cells by complementation of split enhanced green fluorescent protein. J. Virol. 2007, 81, 11532-11537. [CrossRef]

78. Cairns, T.M.; Whitbeck, J.C.; Lou, H.; Heldwein, E.E.; Chowdary, T.K.; Eisenberg, R.J.; Cohen, G.H. Capturing the herpes simplex virus core fusion complex (gB-gH/gL) in an acidic environment. J. Virol. 2011, 85, 6175-6184. [CrossRef]

79. Vanarsdall, A.L.; Howard, P.W.; Wisner, T.W.; Johnson, D.C. Human Cytomegalovirus gH/gL Forms a Stable Complex with the Fusion Protein gB in Virions. PLoS Pathog. 2016, 12, e1005564. [CrossRef]

80. Bowden, R.A.; Slichter, S.J.; Sayers, M.; Weisdorf, D.; Cays, M.; Schoch, G.; Banaji, M.; Haake, R.; Welk, K.; Fisher, L.; et al. A comparison of filtered leukocyte-reduced and cytomegalovirus (CMV) seronegative blood products for the prevention of transfusion-associated CMV infection after marrow transplant. Blood 1995, 86, 3598-3603.

81. Lipson, S.M.; Shepp, D.H.; Match, M.E.; Axelrod, F.B.; Whitbread, J.A. Cytomegalovirus infectivity in whole blood following leukocyte reduction by filtration. Am. J. Clin. Pathol. 2001, 116, 52-55. [CrossRef] [PubMed]

82. Spector, S.A.; Hsia, K.; Crager, M.; Pilcher, M.; Cabral, S.; Stempien, M.J. Cytomegalovirus (CMV) DNA load is an independent predictor of CMV disease and survival in advanced AIDS. J. Virol. 1999, 73, 7027-7030. [PubMed]

83. Sinzger, C.; Schmidt, K.; Knapp, J.; Kahl, M.; Beck, R.; Waldman, J.; Hebart, H.; Einsele, H.; Jahn, G. Modification of human cytomegalovirus tropism through propagation in vitro is associated with changes in the viral genome. J. Gen. Virol. 1999, 80 Pt 11, 2867-2877. [CrossRef]

84. Yamane, Y.; Furukawa, T.; Plotkin, S.A. Supernatant virus release as a differentiating marker between low passage and vaccine strains of human cytomegalovirus. Vaccine 1983, 1, 23-25. [CrossRef] 
85. Dargan, D.J.; Douglas, E.; Cunningham, C.; Jamieson, F.; Stanton, R.J.; Baluchova, K.; McSharry, B.P.; Tomasec, P.; Emery, V.C.; Percivalle, E.; et al. Sequential mutations associated with adaptation of human cytomegalovirus to growth in cell culture. J. Gen. Virol. 2010, 91, 1535-1546. [CrossRef] [PubMed]

86. Stanton, R.J.; Baluchova, K.; Dargan, D.J.; Cunningham, C.; Sheehy, O.; Seirafian, S.; McSharry, B.P.; Neale, M.L.; Davies, J.A.; Tomasec, P.; et al. Reconstruction of the complete human cytomegalovirus genome in a BAC reveals RL13 to be a potent inhibitor of replication. J. Clin. Investig. 2010, 120, 3191-3208. [CrossRef] [PubMed]

87. Cortese, M.; Calo, S.; D'Aurizio, R.; Lilja, A.; Pacchiani, N.; Merola, M. Recombinant human cytomegalovirus (HCMV) RL13 binds human immunoglobulin G Fc. PLoS ONE 2012, 7, e50166. [CrossRef]

88. Laib Sampaio, K.; Stegmann, C.; Brizic, I.; Adler, B.; Stanton, R.J.; Sinzger, C. The contribution of pUL74 to growth of human cytomegalovirus is masked in the presence of RL13 and UL128 expression. J. Gen. Virol. 2016, 97, 1917-1927. [CrossRef]

89. Murrell, I.; Bedford, C.; Ladell, K.; Miners, K.L.; Price, D.A.; Tomasec, P.; Wilkinson, G.W.G.; Stanton, R.J. The pentameric complex drives immunologically covert cell-cell transmission of wild-type human cytomegalovirus. Proc. Natl. Acad. Sci. USA 2017, 114, 6104-6109. [CrossRef]

90. Silva, M.C.; Schroer, J.; Shenk, T. Human cytomegalovirus cell-to-cell spread in the absence of an essential assembly protein. Proc. Natl. Acad. Sci. USA 2005, 102, 2081-2086. [CrossRef]

91. Zhou, M.; Yu, Q.; Wechsler, A.; Ryckman, B.J. Comparative analysis of gO isoforms reveals that strains of human cytomegalovirus differ in the ratio of $\mathrm{gH} / \mathrm{gL} / \mathrm{gO}$ and $\mathrm{gH} / \mathrm{gL} / \mathrm{UL} 128-131$ in the virion envelope. J. Virol. 2013, 87, 9680-9690. [CrossRef] [PubMed]

92. Murphy, E.; Yu, D.; Grimwood, J.; Schmutz, J.; Dickson, M.; Jarvis, M.A.; Hahn, G.; Nelson, J.A.; Myers, R.M.; Shenk, T.E. Coding potential of laboratory and clinical strains of human cytomegalovirus. Proc. Natl. Acad. Sci. USA 2003, 100, 14976-14981. [CrossRef] [PubMed]

93. Sinzger, C.; Hahn, G.; Digel, M.; Katona, R.; Sampaio, K.L.; Messerle, M.; Hengel, H.; Koszinowski, U.; Brune, W.; Adler, B. Cloning and sequencing of a highly productive, endotheliotropic virus strain derived from human cytomegalovirus TB40/E. J. Gen. Virol. 2008, 89, 359-368. [CrossRef] [PubMed]

94. Hahn, G.; Khan, H.; Baldanti, F.; Koszinowski, U.H.; Revello, M.G.; Gerna, G. The human cytomegalovirus ribonucleotide reductase homolog UL45 is dispensable for growth in endothelial cells, as determined by a BAC-cloned clinical isolate of human cytomegalovirus with preserved wild-type characteristics. J. Virol. 2002, 76, 9551-9555. [CrossRef] [PubMed]

95. Murrell, I.; Tomasec, P.; Wilkie, G.S.; Dargan, D.J.; Davison, A.J.; Stanton, R.J. Impact of sequence variation in the UL128 locus on production of human cytomegalovirus in fibroblast and epithelial cells. J. Virol. 2013, 87, 10489-10500. [CrossRef] [PubMed]

96. Cha, T.A.; Tom, E.; Kemble, G.W.; Duke, G.M.; Mocarski, E.S.; Spaete, R.R. Human cytomegalovirus clinical isolates carry at least 19 genes not found in laboratory strains. J. Virol. 1996, 70, 78-83. [PubMed]

97. Li, G.; Nguyen, C.C.; Ryckman, B.J.; Britt, W.J.; Kamil, J.P. A viral regulator of glycoprotein complexes contributes to human cytomegalovirus cell tropism. Proc. Natl. Acad. Sci. USA 2015, 112, 4471-4476. [CrossRef]

98. Nguyen, C.C.; Siddiquey, M.N.A.; Zhang, H.; Li, G.; Kamil, J.P. Human Cytomegalovirus Tropism Modulator UL148 Interacts with SEL1L, a Cellular Factor That Governs Endoplasmic Reticulum-Associated Degradation of the Viral Envelope Glycoprotein gO. J. Virol. 2018, 92, e00688-18. [CrossRef]

99. Wang, E.C.Y.; Pjechova, M.; Nightingale, K.; Vlahava, V.M.; Patel, M.; Ruckova, E.; Forbes, S.K.; Nobre, L.; Antrobus, R.; Roberts, D.; et al. Suppression of costimulation by human cytomegalovirus promotes evasion of cellular immune defenses. Proc. Natl. Acad. Sci. USA 2018, 115, 4998-5003. [CrossRef]

100. Siddiquey, M.N.A.; Zhang, H.; Nguyen, C.C.; Domma, A.J.; Kamil, J.P. The Human Cytomegalovirus Endoplasmic Reticulum-Resident Glycoprotein UL148 Activates the Unfolded Protein Response. J. Virol. 2018, 92, e00896-18. [CrossRef]

101. Luganini, A.; Cavaletto, N.; Raimondo, S.; Geuna, S.; Gribaudo, G. Loss of the Human Cytomegalovirus US16 Protein Abrogates Virus Entry into Endothelial and Epithelial Cells by Reducing the Virion Content of the Pentamer. J. Virol. 2017, 91, e00205-17. [CrossRef] [PubMed]

102. Borza, C.M.; Hutt-Fletcher, L.M. Alternate replication in B cells and epithelial cells switches tropism of Epstein-Barr virus. Nat. Med. 2002, 8, 594-599. [CrossRef] [PubMed]

103. McGeoch, D.J.; Cook, S.; Dolan, A.; Jamieson, F.E.; Telford, E.A. Molecular phylogeny and evolutionary timescale for the family of mammalian herpesviruses. J. Mol. Biol. 1995, 247, 443-458. [CrossRef] [PubMed] 
104. Wagner, M.; Gutermann, A.; Podlech, J.; Reddehase, M.J.; Koszinowski, U.H. Major histocompatibility complex class I allele-specific cooperative and competitive interactions between immune evasion proteins of cytomegalovirus. J. Exp. Med. 2002, 196, 805-816. [CrossRef] [PubMed]

105. Krmpotic, A.; Bubic, I.; Polic, B.; Lucin, P.; Jonjic, S. Pathogenesis of murine cytomegalovirus infection. Microbes Infect. 2003, 5, 1263-1277. [CrossRef] [PubMed]

106. Streblow, D.N.; Hwee, Y.K.; Kreklywich, C.N.; Andoh, T.; Denton, M.; Smith, P.; Hart, E.; Broekel, R.; Pallett, C.; Rogers, K.; et al. Rat Cytomegalovirus Vaccine Prevents Accelerated Chronic Rejection in CMV-Naive Recipients of Infected Donor Allograft Hearts. Am. J. Transpl. 2015, 15, 1805-1816. [CrossRef] [PubMed]

107. Itell, H.L.; Kaur, A.; Deere, J.D.; Barry, P.A.; Permar, S.R. Rhesus monkeys for a nonhuman primate model of cytomegalovirus infections. Curr. Opin. Virol. 2017, 25, 126-133. [CrossRef] [PubMed]

108. Lockridge, K.M.; Sequar, G.; Zhou, S.S.; Yue, Y.; Mandell, C.P.; Barry, P.A. Pathogenesis of experimental rhesus cytomegalovirus infection. J. Virol. 1999, 73, 9576-9583. [PubMed]

109. Bradford, R.D.; Yoo, Y.G.; Golemac, M.; Pugel, E.P.; Jonjic, S.; Britt, W.J. Murine CMV-induced hearing loss is associated with inner ear inflammation and loss of spiral ganglia neurons. PLoS Pathog. 2015, 11, e1004774. [CrossRef] [PubMed]

110. Hansen, S.G.; Piatak, M., Jr.; Ventura, A.B.; Hughes, C.M.; Gilbride, R.M.; Ford, J.C.; Oswald, K.; Shoemaker, R.; Li, Y.; Lewis, M.S.; et al. Immune clearance of highly pathogenic SIV infection. Nature 2013, 502, 100-104. [CrossRef] [PubMed]

111. Hansen, S.G.; Zak, D.E.; Xu, G.; Ford, J.C.; Marshall, E.E.; Malouli, D.; Gilbride, R.M.; Hughes, C.M.; Ventura, A.B.; Ainslie, E.; et al. Prevention of tuberculosis in rhesus macaques by a cytomegalovirus-based vaccine. Nat. Med. 2018, 24, 130-143. [CrossRef] [PubMed]

112. Oxford, K.L.; Strelow, L.; Yue, Y.; Chang, W.L.; Schmidt, K.A.; Diamond, D.J.; Barry, P.A. Open reading frames carried on $\mathrm{UL} / \mathrm{b}^{\prime}$ are implicated in shedding and horizontal transmission of rhesus cytomegalovirus in rhesus monkeys. J. Virol. 2011, 85, 5105-5114. [CrossRef] [PubMed]

113. Campbell, A.E.; Cavanaugh, V.J.; Slater, J.S. The salivary glands as a privileged site of cytomegalovirus immune evasion and persistence. Med. Microbiol. Immunol. 2008, 197, 205-213. [CrossRef] [PubMed]

114. Farrell, H.E.; Lawler, C.; Tan, C.S.; MacDonald, K.; Bruce, K.; Mach, M.; Davis-Poynter, N.; Stevenson, P.G. Murine Cytomegalovirus Exploits Olfaction To Enter New Hosts. mBio 2016, 7, e00251-16. [CrossRef] [PubMed]

115. Yunis, J.; Farrell, H.E.; Bruce, K.; Lawler, C.; Wyer, O.; Davis-Poynter, N.; Brizic, I.; Jonjic, S.; Adler, B.; Stevenson, P.G. Murine Cytomegalovirus glycoprotein O promotes epithelial cell infection in vivo. J. Virol. 2018. [CrossRef] [PubMed]

116. Lemmermann, N.A.; Krmpotic, A.; Podlech, J.; Brizic, I.; Prager, A.; Adler, H.; Karbach, A.; Wu, Y.; Jonjic, S.; Reddehase, M.J.; et al. Non-redundant and redundant roles of cytomegalovirus $\mathrm{gH} / \mathrm{gL}$ complexes in host organ entry and intra-tissue spread. PLoS Pathog. 2015, 11, e1004640. [CrossRef] [PubMed]

117. McGeoch, D.J.; Rixon, F.J.; Davison, A.J. Topics in herpesvirus genomics and evolution. Virus Res. 2006, 117, 90-104. [CrossRef]

118. Vales-Gomez, M.; Browne, H.; Reyburn, H.T. Expression of the UL16 glycoprotein of Human Cytomegalovirus protects the virus-infected cell from attack by natural killer cells. BMC Immunol. 2003, 4, 4 . [CrossRef]

119. Wu, J.; Chalupny, N.J.; Manley, T.J.; Riddell, S.R.; Cosman, D.; Spies, T. Intracellular retention of the MHC class I-related chain B ligand of NKG2D by the human cytomegalovirus UL16 glycoprotein. J. Immunol. 2003, 170, 4196-4200. [CrossRef]

120. Welte, S.A.; Sinzger, C.; Lutz, S.Z.; Singh-Jasuja, H.; Sampaio, K.L.; Eknigk, U.; Rammensee, H.G.; Steinle, A. Selective intracellular retention of virally induced NKG2D ligands by the human cytomegalovirus UL16 glycoprotein. Eur. J. Immunol. 2003, 33, 194-203. [CrossRef]

121. Sturgill, E.R.; Malouli, D.; Hansen, S.G.; Burwitz, B.J.; Seo, S.; Schneider, C.L.; Womack, J.L.; Verweij, M.C.; Ventura, A.B.; Bhusari, A.; et al. Natural Killer Cell Evasion Is Essential for Infection by Rhesus Cytomegalovirus. PLoS Pathog. 2016, 12, e1005868. [CrossRef] [PubMed]

122. Vink, C.; Beuken, E.; Bruggeman, C.A. Complete DNA sequence of the rat cytomegalovirus genome. J. Virol. 2000, 74, 7656-7665. [CrossRef] [PubMed] 
123. Yang, D.; Tamburro, K.; Dittmer, D.; Cui, X.; McVoy, M.A.; Hernandez-Alvarado, N.; Schleiss, M.R. Complete genome sequence of pathogenic Guinea pig cytomegalovirus from salivary gland homogenates of infected animals. Genome Announc. 2013, 1, e0005413. [CrossRef] [PubMed]

124. Ettinger, J.; Geyer, H.; Nitsche, A.; Zimmermann, A.; Brune, W.; Sandford, G.R.; Hayward, G.S.; Voigt, S. Complete genome sequence of the english isolate of rat cytomegalovirus (Murid herpesvirus 8). J. Virol. 2012, 86, 13838. [CrossRef] [PubMed]

125. Smith, L.M.; McWhorter, A.R.; Masters, L.L.; Shellam, G.R.; Redwood, A.J. Laboratory strains of murine cytomegalovirus are genetically similar to but phenotypically distinct from wild strains of virus. J. Virol. 2008, 82, 6689-6696. [CrossRef] [PubMed]

126. Rawlinson, W.D.; Farrell, H.E.; Barrell, B.G. Analysis of the complete DNA sequence of murine cytomegalovirus. J. Virol. 1996, 70, 8833-8849. [PubMed]

127. Oxford, K.L.; Eberhardt, M.K.; Yang, K.W.; Strelow, L.; Kelly, S.; Zhou, S.S.; Barry, P.A. Protein coding content of the UL)b' region of wild-type rhesus cytomegalovirus. Virology 2008, 373, 181-188. [CrossRef] [PubMed]

128. Scrivano, L.; Esterlechner, J.; Muhlbach, H.; Ettischer, N.; Hagen, C.; Grunewald, K.; Mohr, C.A.; Ruzsics, Z.; Koszinowski, U.; Adler, B. The m74 gene product of murine cytomegalovirus (MCMV) is a functional homolog of human CMV gO and determines the entry pathway of MCMV. J. Virol. 2010, 84, 4469-4480. [CrossRef] [PubMed]

129. Wagner, F.M.; Brizic, I.; Prager, A.; Trsan, T.; Arapovic, M.; Lemmermann, N.A.; Podlech, J.; Reddehase, M.J.; Lemnitzer, F.; Bosse, J.B.; et al. The viral chemokine MCK-2 of murine cytomegalovirus promotes infection as part of a gH/gL/MCK-2 complex. PLoS Pathog. 2013, 9, e1003493. [CrossRef]

130. Coleman, S.; Choi, K.Y.; Root, M.; McGregor, A. A Homolog Pentameric Complex Dictates Viral Epithelial Tropism, Pathogenicity and Congenital Infection Rate in Guinea Pig Cytomegalovirus. PLoS Pathog. 2016, 12, e1005755. [CrossRef]

131. Lilja, A.E.; Shenk, T. Efficient replication of rhesus cytomegalovirus variants in multiple rhesus and human cell types. Proc. Natl. Acad. Sci. USA 2008, 105, 19950-19955. [CrossRef]

132. Malouli, D.; Nakayasu, E.S.; Viswanathan, K.; Camp, D.G., 2nd; Chang, W.L.; Barry, P.A.; Smith, R.D.; Fruh, K. Reevaluation of the coding potential and proteomic analysis of the BAC-derived rhesus cytomegalovirus strain 68-1. J. Virol. 2012, 86, 8959-8973. [CrossRef] [PubMed]

133. Miura, T.; Makino, R.; Yamada, K.; Matsuura, M.; Okumura, M.; Yamada, S.; Watanabe, S.; Inoue, N. Differences in the effects of mutations in GP131, a guinea pig cytomegalovirus homologue of pentameric complex component UL130, on macrophage and epithelial cell infection. J. Gen. Virol. 2018, 99, 1425-1431. [CrossRef] [PubMed]

134. McVoy, M.A.; Wang, J.B.; Dittmer, D.P.; Bierle, C.J.; Swanson, E.C.; Fernandez-Alarcon, C.; Hernandez-Alvarado, N.; Zabeli, J.C.; Schleiss, M.R. Repair of a Mutation Disrupting the Guinea Pig Cytomegalovirus Pentameric Complex Acquired during Fibroblast Passage Restores Pathogenesis in Immune-Suppressed Guinea Pigs and in the Context of Congenital Infection. J. Virol. 2016, 90, 7715-7727. [CrossRef] [PubMed]

135. Beisser, P.S.; Kaptein, S.J.; Beuken, E.; Bruggeman, C.A.; Vink, C. The Maastricht strain and England strain of rat cytomegalovirus represent different betaherpesvirus species rather than strains. Virology 1998, 246, 341-351. [CrossRef] [PubMed]

136. Pontejo, S.M.; Murphy, P.M. Chemokines encoded by herpesviruses. J. Leukoc. Biol. 2017, 102, $1199-1217$. [CrossRef] [PubMed]

(C) 2018 by the authors. Licensee MDPI, Basel, Switzerland. This article is an open access article distributed under the terms and conditions of the Creative Commons Attribution (CC BY) license (http:/ / creativecommons.org/licenses/by/4.0/). 